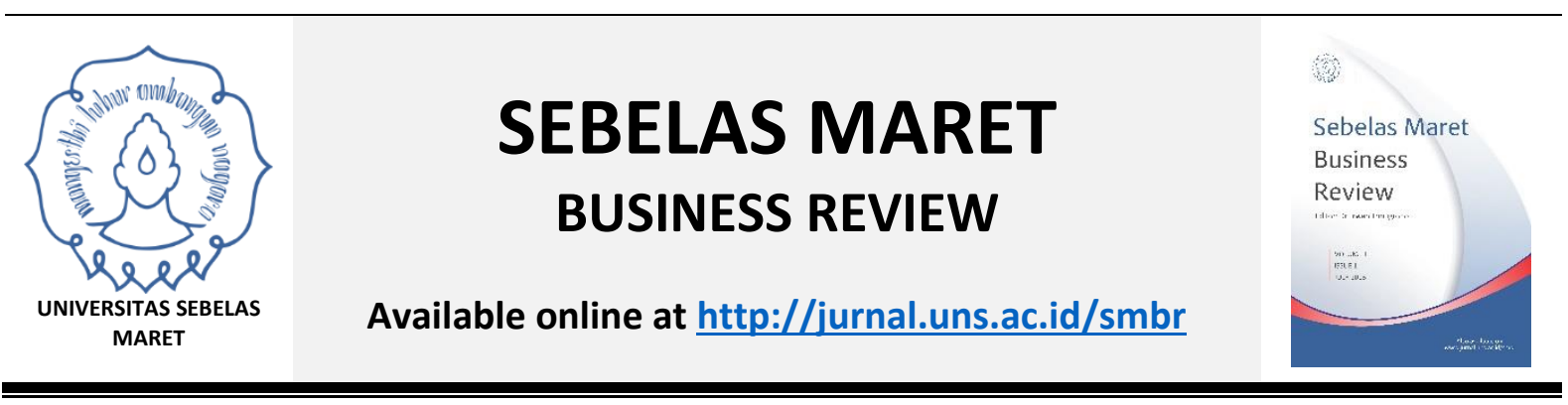

\title{
Market Reaction to the Fed Quantitative Easing Policy: Indonesian Evidence
}

\author{
Sevanrhoo Noya Dean Tanardi and Irwan Trinugroho ${ }^{1}$ \\ Faculty of Economics and Business, Universitas Sebelas Maret \\ 1Email: irwan.trinugroho@gmail.com
}

\begin{tabular}{|c|c|}
\hline ARTICLE INFO & ABSTRACT \\
\hline Article History: & \multirow{10}{*}{$\begin{array}{l}\text { We examine the information content of the announcements } \\
\text { of quantitative easing policy by The Fed in } 2008,2010 \text { and } \\
2012 \text { on the stock price of firms listed in the Indonesia } \\
\text { Stock Exchange, more particular firms with liquid stocks } \\
\text { included in the list of LQ45. Moreover, we also investigate } \\
\text { the determinants of abnormal return by focusing on the } \\
\text { effect differences between foreign-controlled and domestic } \\
\text { firms as well as between crisis and non-crisis period. Event } \\
\text { study and OLS regression are employed to examine our } \\
\text { hypotheses. We find that there are significant abnormal } \\
\text { returns around the announcement dates both during the } \\
\text { crisis and non-crisis period. No evidence is found on the } \\
\text { difference between foreign-controlled and domestic firms. }\end{array}$} \\
\hline Received 29 June 2017 & \\
\hline $\begin{array}{l}\text { Received in Revised } \\
\text { Form }\end{array}$ & \\
\hline Accepted 3 July 2017 & \\
\hline $\begin{array}{l}\text { Available online } 5 \text { July } \\
\quad 2017\end{array}$ & \\
\hline Keywords: & \\
\hline Quantitative easing, & \\
\hline Abnormal return, & \\
\hline Global crisis financial, & \\
\hline & \\
\hline
\end{tabular}

\section{INTRODUCTION}

It is generally known that financial market is strongly affected by economic factors. The changes in macro-economic policies and conditions such as interest rate, foreign exchange, inflation, and others, could affect the stock price traded in the markets. The effect of monetary policy on capital market has been widely studied. Bernanke and Kuttner (2005) show that decreasing interest rate by 25 points would result in the increase in stock index by $1 \%$. Subprime mortgage crisis that leads to the bankruptcy of several US financial institutions 2008 is also an appropriate example. The bankruptcy 
started when The Fed (US central bank) decreased the interest rate to overly lower level. The low interest rate was then exploited by property agency and property financing agency to build and sell houses with low price to people with low income, mostly they do not have proper collateral. The increase in mortgage then led to the increase in the accumulation of bad debts due to the debtors have no ability to pay their mortgage. The accumulation of bad debts ignites domino effect which ends in the bankruptcy of several US financial institutions. To overcome this situation, The Fed launched an unusual financial policy in the form of quantitative easing which is a form of unconventional monetary policy (Joyce et al., 2012).

The quantitative easing is basically providing monetary stimulus by purchasing mortgage backed securities (MBS) and government financial product (treasury notes). Quantitative easing was decided based on the result of Federal Open Market Committee (FOMC) meeting under The Fed control. The three steps of this quantitative easing were as follows. a) First round quantitative easing on November 25, 2008 when the Fed announced that it will emit $\$ 600$ billion to MBS and money market. On December 16 , 2008, this policy was officially announced by Federal Open Market Committee (FOMC). b) Second round quantitative easing on November 3, 2010 in which the Fed announced the plan to purchase bonds up to $\$ 600$ billion with $\$ 75$ billion each month and would end in June 2011. c) Third round quantitative easing on September 13, 2012 in which The Fed announced a commitment to purchase $\$ 40$ billion assets backed MBS for each month.

The financial institutions that receive fresh money from quantitative easing policy could exploit the money to generate profits by distributing the fund as a credit and generate income from the interest or by utilizing the fund for various investment instruments outside US due to the surplus of currency and the weakening of USD. Those policies lead investors to move their investment to emerging markets that have high economic growth such as Indonesia. Indonesia's consistent positive growth in the last few years before the crisis has attracted foreign investments. According to the Indonesian market statistic, there is an increase of trading value of foreign investors in the Indonesia Stock Exchange (IDX) around the dates of quantitative easing announcements. Abimanyu (2008) explains that the quantitative easing policy released by the Fed affects the Indonesian market due to the co-integration between Indonesian financial market and the US financial market. Angraheni and Sukamulja (2014), by studying time series data of Indonesian LQ45 index and employing GARCH, TARCH, and Granger causality test, find the positive effect of quantitative easing on stock return. Therefore, they argue that quantitative easing is considered to be good news, in which market responses positively to this policy.

This present paper deals with the market reaction in the Indonesian stock market to the announcement of quantitative easing policy by the Fed in 2008, 2010 and 2012. Going deeper, we also estimate regression models to explain the determinants of abnormal return around the announcement of quantitative easing policy. We stress on two particular aspects. First, we test whether the abnormal returns are more pronounced during the global financial crisis. Second, we emphazise the effect of such policy for foreign-controlled firms. Some previous studies (e.g. Manlagnit, 2011; Trinugroho et al., 2014; Chhibber and Majumdar, 1999) reveal that foreign-controlled firms are more efficiency and better in management. It leads that those firms are less volatile to the global issues. Therefore, it could be argued that foreign-controlled firms would be less affected by the quantitative easing policy. To our knowledge, there is no study focusing on Indonesian market with regard to the announcement of quantitative easing policy using event study. 


\section{RESEARCH METHOD}

This study employs event study method to test market reaction in IDX on the announcement of quantitative easing policy by The Fed in three rounds; 2008 (first round), 2010 (second round), and 2012 (third round). We also run some regression models to investigate the determinants of abnormal returns around the announcement dates.

\section{Data}

We study Indonesian listed firms which are most liquid (included in the list of LQ45). Data are gathered from the www.idx.co.id, www.yahoofinance.com and the Indonesia Capital Market Directory (ICMD). We include stocks that are in the list of LQ45 index in November 2008 and September 2012 which have complete information on stock price and financial reports. However, we exclude firms conducting corporate actions during the announcement dates. Finally, 131 firms are included in the analysis.

\section{Event Study}

To test the market reaction of Indonesian market to the announcements of quatitative easing policy by the Fed, we perform event study technique to detect the abnormal return around the event dates. According Dyckman et al. (1984), Peterson (1989) and Beverley (2008), abnormal return could provide information content of an event.We establish two window periods which are three days before until three days after the event ( $t-3$ to $t+3$ ) and five days before until five days after the event $(t-5$ to $t+5)$. To estimate the expected return during the event period, we take 100 days before the event period. The event date used in this study is a day after the announcement of quantitative easing policy by The Fed due to the time difference between US and Indonesia. Followings are the event dates $\left(\mathrm{t}_{0}\right)$ :

a. The announcement of the first round quantitative easing took place on November 25, 2008 in US, thus to was November 26, 2008.

b. The announcement of the second round quantitative easing took place on November 3, 2010 in US, thus to was November 4, 2010.

c. The announcement of the third round quantitative easing take place on September 13, 2012 in US, thus to was September 14, 2012.

\section{Regression Analysis}

Further, we also look at the determinants of abnormal returns around the announcement dates which mean that the dependent variable is the cumulative abnormal return (CAR) during the windows period. As explained earlier, we first emphasize on the effect difference between crisis and non-crisis period. Therefore, we create two dummy variables representing the period of 2008 and the period of 2012. Second, we stress on the effect difference between foreign-controlled and domestic firms. To do so, we create a dummy variable taking a value of 1 for foreign-controlled firms and 0 otherwise. We also control for firm specific characteristics which are firm size measured by the natural logarithm of total assets (LNTA) and the financial leverage measured by debt to equity ratio (DER). Industry characteristic is also controlled by including a set of dummy 
variables reflecting industry classification following the study of Prabowo et al (2014). The regression models are as follows:

$$
\begin{aligned}
& C A R_{3 i}=\beta_{0}+\beta_{12008}+\beta_{2} 2012_{i}+\beta_{3} \text { A }_{i}+\beta_{4} D E R_{i}+\beta_{5} \mathrm{FO}_{i}+\beta_{6} \mathrm{AGRI}_{i}+\beta_{7} \mathrm{BACHEM}_{i}+
\end{aligned}
$$

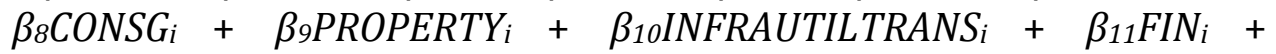

$$
\begin{aligned}
& \beta_{12} \text {TRASERINVEST }_{i}+\beta_{13} \text { MISC }_{i}+\varepsilon_{i} \\
& C_{2 A R}=\beta_{0}+\beta_{12008}+\beta_{22} 2012_{i}+\beta_{3} \text { TA }_{i}+\beta_{4} \text { DER }_{i}+\beta_{5} \mathrm{FO}_{i}+\beta_{6} \text { AGRI }_{i}+\beta_{7} \text { BACHEM }_{i}+
\end{aligned}
$$

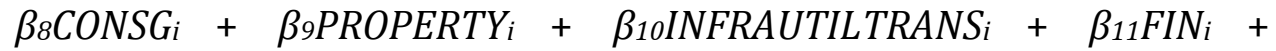

$$
\begin{aligned}
& \beta_{12} \text {TRASERINVEST }_{i}+\beta_{13} \text { MISC }_{i}+\mathcal{E}_{i}
\end{aligned}
$$

Notes:

$\mathrm{CAR}_{3 \mathrm{i}}$

$=$ cumulative abnormal return of stocks in $\mathrm{T}-3$ and $\mathrm{T}+3$

$\mathrm{CAR}_{5 \mathrm{i}}$

$=$ cumulative abnormal return of stocks in $\mathrm{T}-5$ and $\mathrm{T}+5$

$2008 \mathrm{i}$

$=$ dummy variable for 2008

$2012 \mathrm{i}$

= dummy variable for 2012

TAi

= natural logarithm of total assets (ln TA)

DERi

= debt to total equity ratio (DER)

$\mathrm{FO}_{\mathrm{i}}$

= dummy variable for foreign-controlled firms

AGRI $_{i}$

= dummy variable for Agriculture industry

BACHEM $_{i}$

= dummy variable for Basic Industry and Chemicals

CONSGi

PROPERTY

= dummy variable for Consumer Goods industry

= dummy variable for Property, Real Estate, and Building Construction industry

INFRAUTILTRANS $_{\mathrm{i}}=$ dummy variable for Infrastructure, Utilities, and Transportation industry

$\mathrm{FIN}_{\mathrm{i}} \quad$ = dummy variable for Finance industry

TRASERINVEST $_{\mathrm{i}} \quad$ = dummy variable for Trade, Service, and Investment industry

MISC $_{\mathrm{i}}$

= dummy variable for Miscellaneous industry

\section{RESULTS AND DISCUSSION}

\section{a. Event Study}

Table 1 presents the result of one-sample t-test for the abnormal return of quantitative easing policy announcement by The Fed in 2008 (first phase). Accordingly, there are five period that generate significant positive abnormal return for investors which are $t-2, t-1, t+1, t+2$, and $t+5$ period. There is a significant abnormal return around the announcement period of quantitative easing policy by The Fed in 2008. The reaction is negative during the fifth and fourth day before the announcement date. Supposedly, there is an uncertainty about how the government will solve the crisis arises especially with respect to the announcement of quantitative easing. Further, there is no significant reaction on the second and third day before the announcement. It is an indication that investors take a wait \& see position. However, market is shifting to positive during the announcement day, one day before the announcement and second day after the announcement. This condition could be caused by a temporary profit taking action taken by investors. On the third and fourth day after the announcement, there is a significant negative reaction. This is mainly caused by an excessive buying in few days before, which leads to profit taking in the days after. 
Table 1.

One-Sample t-Test for Abnormal Return 2008

\begin{tabular}{|c|c|c|c|}
\hline Days & AAR,t & T-Value & Sig \\
\hline-5 & -0.01506976 & $-2.305^{* *}$ & 0.026 \\
\hline-4 & -0.03096117 & $-5.260^{* * *}$ & 0.000 \\
\hline-3 & -0.00029171 & -0.032 & 0.974 \\
\hline-2 & -0.00103238 & -0.124 & 0.902 \\
\hline-1 & 0.038727601 & $3.705^{* * *}$ & 0.001 \\
\hline 0 & 0.039025456 & $4.909^{* * *}$ & 0.000 \\
\hline 1 & 0.010380177 & 1.243 & 0.221 \\
\hline 2 & 0.046245414 & $5.029^{* * *}$ & 0.000 \\
\hline 3 & -0.01549929 & $-2.571^{* *}$ & 0.014 \\
\hline 4 & -0.03075335 & $-7.302^{* * *}$ & 0.000 \\
\hline 5 & 0.007103875 & 1.116 & 0.271 \\
\hline
\end{tabular}

${ }^{*}$ significant at $10 \%,{ }^{* *}$ significant at $5 \%,{ }^{* * *}$ significant at $1 \%$

The result of event study for the second quantitative easing policy announcement in 2010 (second phase) is presented in Table 2. It is shown that there is a significant abnormal return around the announcement of quantitative easing policy. For several days, especially on the fourth, second, and one day before the announcement, market reacts negatively. Perhaps, this is due to the result of the first quantitative easing in 2008 that is considered to have only few contributions in improving the US economy. However, market reacts positively on the announcement day, first, second, and third day after the announcement day. Therefore, in overall, it could be concluded that the announcement of quantitative easing in 2010 is positively responded by Indonesian market.

Table 2.

One-Sample t-Test for Abnormal Return 2010

\begin{tabular}{|c|c|c|c|}
\hline Day & AAR,t & T-Value & Sig \\
\hline 5 & 0.000776976 & 0.260 & 0.796 \\
\hline 4 & -0.00513681 & $-2.048^{* *}$ & 0.047 \\
\hline 3 & 0.002505277 & 0.713 & 0.480 \\
\hline 2 & -0.00533972 & $-1.981^{* *}$ & 0.054 \\
\hline 1 & -0.01257973 & $-4.551^{* * *}$ & 0.000 \\
\hline 0 & 0.009298198 & $2.936^{* * *}$ & 0.005 \\
\hline 1 & 0.007034907 & $2.077^{* *}$ & 0.044 \\
\hline 2 & 0.007299104 & $2.185^{* *}$ & 0.035 \\
\hline 3 & 0.006061472 & $1.761^{* *}$ & 0.086 \\
\hline 4 & -0.00419976 & -1.582 & 0.122 \\
\hline 5 & -0.0055879 & $-2.466^{* *}$ & 0.018 \\
\hline
\end{tabular}

${ }^{*}$ significant at $10 \%,{ }^{* *}$ significant at $5 \%,{ }^{* * *}$ significant at $1 \%$

The result of event study for the third quantitative easing policy in 2012 (third phase) is presented in table 3. It is shown that there is significant abnormal return around the announcement dates. Market reacts positively on the fifth, third, and second day 
before the announcement, the announcement date, and first, third, and fifth day after the announcement. Supposedly, market is already accustomed and could anticipate the effect of the quantitative easing policy in 2012. Moreover, market may be enjoyed the quantitative easing policy, making more capital inflow to Indonesian financial market.

Table 3.

One-Sample t-Test for Abnormal Return 2012

\begin{tabular}{|c|c|c|c|}
\hline Day & AAR,t & T-Value & Sig \\
\hline 5 & 0.011988782 & $3.962^{* * *}$ & 0.000 \\
\hline 4 & 0.004869565 & 1.673 & 0.101 \\
\hline 3 & 0.004516796 & $2.082^{* *}$ & 0.043 \\
\hline 2 & 0.013159728 & $4.046^{* * *}$ & 0.000 \\
\hline 1 & 0.004578533 & 1.472 & 0.148 \\
\hline 0 & 0.031256907 & $7.993^{* * *}$ & 0.000 \\
\hline 1 & 0.006741688 & $2.058^{* *}$ & 0.046 \\
\hline 2 & -0.00983961 & $-5.632^{* * *}$ & 0.000 \\
\hline 3 & 0.018659796 & $4.074^{* * *}$ & 0.000 \\
\hline 4 & -0.00126142 & -0.298 & 0.767 \\
\hline 5 & 0.008691117 & $2.990^{* * *}$ & 0.005 \\
\hline
\end{tabular}

${ }^{*}$ significant at $10 \%,{ }^{* *}$ significant at $5 \%,{ }^{* * *}$ significant at $1 \%$

\section{b. Regression Results}

The descriptive statistics of variables used in the regression analysis is presented in table 4. Table 5 exhibits the correlation matrix of variables.

Table 4.

Descriptive Statistics

\begin{tabular}{|c|c|c|c|c|c|c|}
\hline & Obs & & CAR3 & CAR5 & TA & DER \\
\hline \multirow{5}{*}{ All Sample } & \multirow{5}{*}{131} & Mean & 0.068578 & 0.048558 & 30.61 & 2.51 \\
\hline & & Median & 0.058083 & 0.044015 & 30.38 & 1.13 \\
\hline & & Maximum & 0.401882 & 0.41375 & 34.01 & 16.10 \\
\hline & & Minimum & -0.586328 & -0.921277 & 28.11 & 0.08 \\
\hline & & Std. Dev. & 0.138773 & 0.163943 & 1.31 & 3.28 \\
\hline \multirow{5}{*}{2008} & \multirow{5}{*}{45} & Mean & 0.117555 & 0.047875 & 30.44 & 3.14 \\
\hline & & Median & 0.132901 & 0.077345 & 30.01 & 1.56 \\
\hline & & Maximum & 0.401882 & 0.41375 & 33.40 & 16.10 \\
\hline & & Minimum & -0.586328 & -0.921277 & 28.11 & 0.22 \\
\hline & & Std. Dev. & 0.200799 & 0.245862 & 1.32 & 3.81 \\
\hline \multirow{5}{*}{2010} & \multirow{5}{*}{41} & Mean & 0.01428 & 0.000132 & 30.62 & 2.43 \\
\hline & & Median & -0.000454 & -0.004976 & 30.27 & 1.09 \\
\hline & & Maximum & 0.190194 & 0.207002 & 33.65 & 10.85 \\
\hline & & Minimum & -0.133049 & -0.105243 & 28.98 & 0.15 \\
\hline & & Std. Dev. & 0.068009 & 0.069517 & 1.28 & 3.18 \\
\hline
\end{tabular}




\begin{tabular}{|c|c|c|c|c|c|c|}
\hline \multirow{5}{*}{2012} & \multirow{5}{*}{45} & Mean & 0.069074 & 0.093362 & 30.77 & 1.97 \\
\hline & & Median & 0.046929 & 0.092438 & 30.57 & 0.73 \\
\hline & & Maximum & 0.309547 & 0.327221 & 34.01 & 10.79 \\
\hline & & Minimum & -0.047661 & -0.091713 & 28.13 & 0.08 \\
\hline & & Std. Dev. & 0.084693 & 0.101637 & 1.35 & 2.72 \\
\hline
\end{tabular}

Table 5.

Correlation Matrix of Variables

Panel A. Correlation between CAR3 and other variables

\begin{tabular}{|l|r|r|r|r|r|r|}
\hline & \multicolumn{1}{|c|}{ CAR3 } & TH2008 & TH2012 & \multicolumn{1}{c|}{ TA } & DER & F0 \\
\hline CAR3 & 1 & & & & & \\
\hline TH2008 & 0.256 & 1 & & & & \\
\hline TH2012 & 0.003 & -0.523 & 1 & & & \\
\hline TA & -0.14 & -0.092 & 0.089 & 1 & & \\
\hline DER & -0.093 & 0.39 & -0.121 & 0.598 & 1 & \\
\hline FO & -0.083 & 0.072 & -0.082 & -0.005 & 0.095 & 1 \\
\hline
\end{tabular}

Panel B. Correlation between CAR5 and other variables

\begin{tabular}{|l|r|r|r|r|r|r|}
\hline & \multicolumn{1}{|c|}{ CAR5 } & TH2008 & TH2012 & \multicolumn{1}{c|}{ TA } & DER & F0 \\
\hline CAR5 & 1 & & & & & \\
\hline TH2008 & -0.003 & 1 & & & & \\
\hline TH2012 & 0.198 & -0.523 & 1 & & & \\
\hline TA & 0.109 & 0.092 & 0.089 & 1 & & \\
\hline DER & -0.132 & 0.139 & -0.102 & 0.598 & 1 & \\
\hline FO & -0.092 & 0.072 & -0.082 & -0.005 & 0.095 & 1 \\
\hline
\end{tabular}

Table 6 shows the regression results, column 1 is for CAR3 and column 2 is for the CAR5. It is clearly shown that the coefficients of dummy variable of 2012 have positive and significant effect on CAR3 and CAR5 which means that the announcement of quantitative easing policy in 2012 has a stronger effect on the Indonesian market. Market reacts positively to this announcement. The announcement in 2008 has also positive and significant effect on CAR3 but no significant effect on CAR5 which means that this announcement has a shorter effect than the announcement in 2012. In overall, it could be concluded that market react positively to the announcement of quantitative easing both in crisis and non-crisis period. Turn to the effect of ownership structure, more particular foreign ownership, on the cumulative abnormal return, we do not find any evidence that foreign-controlled firms are less affected by the quantitative easing policy.

\section{CONCLUSION}

We investigate the effect of quantitative easing policy in the US on the Indonesian financial market by employing event study technique. According to our empirical results, some concluding remaks could be made. First, in aggregate, market reacts positively to the announcements of quantitative easing policy both in the crisis and non-crisis period. Second, there is no different reaction between investors of foreign-controlled firms and 
domestic firms in response to such policy. Overall, this study provides evidence that there is a strong interconnected market between advanced and emerging economies.

Table 6.

Regression Results

The values in brackets are the p-value. $*, * *, * *$ denote significance level at $10 \%$; $5 \% ; 1 \%$, respectively.

\begin{tabular}{|c|c|c|}
\hline \multicolumn{3}{|c|}{ Dependent Variable: Cumulative Abnormal Return (CAR) } \\
\hline & CAR3 & CAR5 \\
\hline \multirow[t]{2}{*}{$\mathrm{C}$} & 0.948719 & 0.854679 \\
\hline & $(0.3447)$ & $(0.3945)$ \\
\hline \multirow[t]{2}{*}{2008} & $3.729646^{* * *}$ & 1.29592 \\
\hline & $(0.0003)$ & $(0.1976)$ \\
\hline \multirow[t]{2}{*}{2012} & $2.05518^{* *}$ & $2.68388^{* * *}$ \\
\hline & $(0.0421)$ & $(0.0083)$ \\
\hline \multirow[t]{2}{*}{ TA } & -0.778946 & -0.769191 \\
\hline & $(0.4376)$ & $(0.4433)$ \\
\hline \multirow[t]{2}{*}{ DER } & -1.209157 & -1.044782 \\
\hline & $(0.229)$ & $(0.2983)$ \\
\hline \multirow[t]{2}{*}{ FO } & -0.914584 & -0.626565 \\
\hline & $(0.3623)$ & $(0.5322)$ \\
\hline \multirow[t]{2}{*}{ AGRI } & -0.177637 & 0.395162 \\
\hline & $(0.8593)$ & $(0.6934)$ \\
\hline \multirow[t]{2}{*}{ BACHEM } & $-2.241798^{* *}$ & -1.407845 \\
\hline & $(0.0269)$ & $(0.1618)$ \\
\hline \multirow[t]{2}{*}{ CONSG } & -1.776596 & -1.39955 \\
\hline & $(0.0782)$ & $(0.1643)$ \\
\hline \multirow[t]{2}{*}{ PROPERTY } & -0.557908 & 0.229576 \\
\hline & $(0.578)$ & $(0.8188)$ \\
\hline \multirow[t]{2}{*}{ INFRAUTILTRANS } & $-2.166859^{* *}$ & -1.068115 \\
\hline & $(0.0323)$ & $(0.2877)$ \\
\hline \multirow[t]{2}{*}{ FIN } & 0.251386 & -0.462633 \\
\hline & $(0.802)$ & $(0.6445)$ \\
\hline \multirow[t]{2}{*}{ TRASERINVEST } & $-2.734486^{* * *}$ & $-1.917768^{*}$ \\
\hline & $(0.0072)$ & $(0.0576)$ \\
\hline \multirow[t]{2}{*}{ MISC } & 0.02262 & 0.593641 \\
\hline & $(0.982)$ & $(0.5539)$ \\
\hline Method & OLS & OLS \\
\hline Observations & 131 & 131 \\
\hline R-squared & 0.227101 & 0.154398 \\
\hline
\end{tabular}




\section{REFERENCES}

Abimanyu, Y., Warsidi, N.S., Kartiko, S., Kurnia, R., Mahrani, T. 2012. International Linkages to The Indonesian Capital Market: Cointegration Test. Kajian Ekonomi dan Keuangan 16(2), 55-76.

Angraheni, B.D., Sukamulja, S. 2014. Analisis Pengaruh Quantitative Easing (QE) Amerika Serikat Terhadap Volatilitas Indeks LQ45 di Bursa Efek Indonesia. http://ejournal.uajy.ac.id/id/eprint/6725

Bernanke, B.S. and Kuttner, K.N. 2005. What Explains the Stock Market's Reaction to Federal Reserve Policy? Journal of Finance 60 (3), 1221-1257.

Beverley, L. 2008. Stock Market Event Studies and Competition Commission Inquiries. CCP Working Paper No. 08-16. Available at SSRN: https://ssrn.com/abstract=1114114

Chhibber, P. K. and Majumdar, S. K. 1999. Foreign ownership and profitability: property rights, control and the performance of firms in Indian Industry. Journal of Law and Economics, 42(1), 209-238.

Dyckman, T., Philbrick, D., Stephan, J. 1984. A Comparison of Event Study Methodologies Using Daily Stock Returns: A Simulation Approach. Journal of Accounting Research 22, 1-30.

Joyce, M., Miles, D., Scott, A., Vayanos, D. 2012. Quantitative Easing and Unconventional Monetary Policy - An Introduction. The Economic Journal, 122, 271-288.

Manlagnit, M.C.V. 2011. The economic effects of foreign bank presence: Evidence from the Philippines. Journal of International Money and Finance 30, 1180-1194.

Peterson, P.P. 1989. Event Studies: A Review of Issues and Methodology. Quarterly Journal of Business and Economics 28(3), 36-66.

Prabowo, M.A., Untoro, W., Trinugroho, I., Angriawan, A. 2014. State-owned Enterprises, Efficiency and Performance: The Case of Indonesia. International Business Management 8(2), 153-158.

Trinugroho, I., Agusman, A., Tarazi, A. 2014. Why have bank interest margins been so high in Indonesia since the 1997/1998 financial crisis? Research in International Business and Finance 32, 139-158 